Snezana Ristevka-Jovanovska ${ }^{1}$

Ana Dimovska ${ }^{2}$

\title{
MARKETING ACTIVITIES AND SALES OF MACEDONIAN WINERIES IN A CONDITION OF PANDEMIC COVID-19
}

\begin{abstract}
Covid-19 has implications on the overall operation of Macedonian wineries and directly affected the decline in domestic sales and export to international markets. The HORECA sector stopped working completely or partially in all countries. The crisis affected the partial or total cuts of marketing costs, by postponing or cancelling planned projects. The wineries failed to sell the planned quantities and were forced to make significantly lower purchases for the 2020 harvest than in previous years.

The paper presents a large number of data received from the Association Wines of Macedonia, Customs Office of the Republic of North Macedonia, Ministry of Agriculture, Forestry and Water Economy of the Republic of North Macedonia, State Inspectorate for Agriculture, Internet articles containing topics relevant to the resear$c h$. The additional data presented were collected from Macedonian wineries through a questionnaire on operations during the corona crisis.

This paper provides an overview of the problems faced by Macedonian wineries during the corona crisis in terms of marketing and sales, primarily in international markets and analyzes the declined average price and reduced investment in marketing.
\end{abstract}

Keywords: North Macedonia, Macedonian wineries, Covid-19, implications, marketing, wine

JEL: $M 30$

$1 \mathrm{PhD}$, Full time professor, University St. Cyril and Methodius, Faculty of economics, E-mail: Snezana.ristevska-jovanovska@eccf.ukim.edu.mk

$2 \mathrm{PhD}$, University St. Cyril and Methodius, Faculty of economics, Vostanicka 118-19, 1000 Skopje, Phone: +38975287888, E-mail: stankovska_ana@yahoo.com 


\section{INTRODUCTION}

The crisis caused by Covid-19 affected the normal functioning of all life segments and indirectly influenced the change of wine consumption worldwide. According to ProWein (n.d.), $80 \%$ of the wineries in 2020 had to reduce their costs to survive or delay planned innovations and investments. Most of them used state measures to be able to pay their employees. One in five manufacturers had to lay off workers.

Wine is a symbol of North Macedonia where it has been produced since ancient times. Many artefacts on ancient sites testify the 4000 years long tradition of viticulture and winemaking (Wines of Macedonia, 2020b). Further, wine is the second largest exported agricultural product after tobacco and participates with 17 to $20 \%$ in the gross domestic product (Wines of Macedonia, 2020c). What is even more important, the wine industry is one of the few Macedonian net export industries, because the raw materials used for production are entirely domestic (Zdravkovska-Stojcevska, 2020).

The wine industry annually buys about 130,000 tons of grapes, depending on the harvest and produces 95-120 million liters of wine, which directly affects the development of agriculture (The Economic Chamber of Macedonia, 2020). Over 85\% of the produced Macedonian wine is exported to foreign markets, and about $15 \%$ is intended for the domestic market. About $50 \%$ of the exported wine is in bottles, and the rest is sold as bulk wine (Zdravkovska-Stojcevska, 2020).

Because of the importance of the Macedonian wine industry for the country, it is of a great interest to mitigate the consequences of the crisis with Covid-19. The pandemic caused big damage to the sales, the harvest and the export of wine and completely endangered the financial liquidity of the wineries. The effects of the "new normality" meant going several years back to the whole category of wine.

Simultaneously, the catering and tourist facilities where wine is consumed were completely or partially closed. This change that occurred globally, not only in Northern Macedonia, reflected in a drastic reduction in sales in these channels. On the other hand, cheaper wines were bought and there was an increase in the consumption of bag-in-box wines (International Organisation of Vine and Wine, 2020). Although the buyers were completely oriented to the trade facilities and towards the lower price segments with wine, large quantities remained unsold, the demand for wine decreased due to the ban on public gathering and the impossibility of organizing celebrations and events. By contrast, the crisis with Covid-19 gave the wineries a chance to reach new customers. During the pandemic, people showed a bigger interest in cooking and experimenting with new recipes, which increased the domestic consumption of wine during meals. Many consumers have shifted their budget to buying premium wines in stores, due to the inability to enjoy them in restaurants. Marketing 
activities that were more focused on activities in the HORECA sector (hotels, restaurants and café bars), started to focus on online activities, as well as the cooperation with facilities that offer delivery and direct sales to consumers. The pandemic has boosted traffic to online sales sites, and so, many wineries have acknowledged the importance of digital media not only for connecting with fans, but also for revealing their specific requirements and preferences (The IWSR, n.d.).

Although many consumers spoiled themselves at home during the pandemic, experts still expect it to have a negative impact on the wine industry and lead to more price-sensitive consumers and an increase in sales of the lower price segments. The recovery of world wine sales as a whole is expected after the end of the Covid-19 crisis (ProWein, n.d.).

\section{Methodology}

This research aimed to explore the challenges which Macedonian wineries faced during the corona crisis in 2020 in terms of marketing and sales, primarily in the international markets. In order to do so, a survey of export managers in the largest Macedonian wineries was conducted in order to see how much and whether the pandemic affected the company's operations, which markets were most affected and what activities they undertook in order to respond to the new market situation. The survey was conducted online in the period from 30.12-2020 to 04.01.2021, and the questionnaire was completed by the export managers of the 10 largest wineries. On the whole, they are representing Macedonian wineries that cover $95 \%$ of the total export of bottled wine and $60 \%$ of the export of bulk wine.

This paper contains secondary data obtained from relevant and reliable institutions, such as the Customs Office of the Republic of North Macedonia, the association "Wines of Macedonia" and the Ministry of Agriculture, Forestry and Water Economy and Wines of Macedonia. A comparison of wine export in the last 3 years was made in order to see the impact of the crisis in the last year while presenting the data in graphs for better graphical visibility.

Internet articles were also used as secondary data, as well as research papers published by wine organizations and associations around the world.

The data analyses were made through the application of several scientific analytic approaches involving analysis, synthesis and comparison. 


\section{The impact of Covid-19 on the Macedonian wine market}

The global pandemic has completely changed the daily shopping habits of consumers, increasing the use of digital services, online payments and e-commerce. Due to the impossibility of leaving their homes in periods of quarantine, consumers have rapidly started to use digital shopping and communication, and their availability has increased worldwide.

In the first part of 2020, the pandemic caused an $80 \%$ loss in the sale of wine on the domestic market during the months when an artificial closure of the market occurred. This huge drop in turnover was caused by the closure and restrictions in the operation of hospitality facilities, where in fact, the largest sale of bottled wine takes place. The biggest wineries present on the Macedonian wine market were the most affected by this situation. After the partial reopening of the market in the summer, the losses decreased, but then again, the wineries operated with reduced sales (Tikves Winery, 2020).

Of course, the time constraints for buying the necessary household groceries from the retail outlets also had an impact. This has led to a complete reduction in sales of HORECA packaging and products on which the profitability of the entire food \& beverages industry is based. On the other hand, in the focus of the purchase were: value for money wines that last longer and the creation of stocks for home consumption.

With the market restrictive measures, the most affected were the wineries whose sale is fully or mostly realized through HORECA facilities. This primarily refers to wineries whose portfolio includes premium wines with higher prices such as Bovin, Kamnik, Lazar, etc. But, in 2020, not only the premium wine segment was affected, but also there was an evident decline in the value of the entire wine category. The domestic sales in 2020 were reduced by $18 \%$ in quantity and even $30 \%$ in value as compared to sales in 2019. Additionally, there was a $10 \%$ decrease in the average value of a liter of wine, which decreased from 2.20 euros in 2019 to 2 euros in 2020 (Tikves Winery, 2021).

This situation forced the Macedonian wineries to make a complete transformation in their operations and find new ways to achieve sales and make up for lost sales - home delivery, e-commerce, combo packages with restaurants, the launch of new innovative products and packaging, etc.

In comparison to more developed markets, consumers in emerging markets such as North Macedonia are more receptive to technology because they lack closeness and trust. Despite limited internet access, consumers are reluctant to shop online due to uncertainty about how their personal information will be stored and used. Emerging markets are generally lagging in the adoption of digital products and services, yet 
these technologies have become indispensable in everyday life during the pandemic (In Store, 2020).

The closed catering and event facilities, as well as the impossibility of placing premium wines to the consumers through the HORECA channel, led to artificial growth of the cheaper wines which took over a part of the market share of value for money and premium wines. In 2020, compared to 2019 the following changes occurred (Tikves Winery, 2021):

- Growth of the share of the cheap wines by $6 \%$, from $67 \%$ to $73 \%$

- Decrease in value for money wines by $4 \%$ - a decrease from $26 \%$ to $22 \%$

- Decrease in premium wines by $2 \%$ - decrease from $7 \%$ to $5 \%$

This indicates that the crisis with Covid-19 has not only reduced sales in the domestic market, but also changed the structure of wine sales.

\section{The impact of Covid-19 on the export of Macedonian wines}

Along with the sale on the domestic market, the pandemic also affected the export of Macedonian wine. According to Ivanovic (2020), the efforts of large producers from Italy, Spain and France to get rid of large stocks of wine, contributed to a reduction in prices by more than $25 \%$, and this indirectly affected the wineries in North Macedonia, that export large quantities of wine to these markets.

The Macedonian wine industry still bears the burden of mass wine production and its sale as bulk, imposed in the time of socialism where the main stimulus was the higher yield of grapes for the production of large quantities of wine. Macedonian wine is exported to 38 countries in the world, which indicates that the industry is highly export dependent and must constantly be aimed at opening new perspectives that mean improving the quality of the wine, experimenting with local varieties, following global trends to maintain the position on the existing markets and, of course, opening up new markets (Pancevska, 2021).

Due to the strategic importance of wine for North Macedonia, the Ministry of Economy has provided measures to support cluster associations through which companies can jointly operate in foreign markets. This will have an additional impetus for the growth of the trade exchange, especially for the increase of Macedonian export (Ministry of Economy, 2020).

Besides the wine events and fairs in the country, the most important wine fairs in the world were also cancelled, such as ProWein in Germany and Vinitaly in Verona. The organization of wine tastings and competitions was also completely disrupted 
and they were moved. Digital online editions have been tried for some of the events, but the feedback is unclear (International Organization of Vine and Wine, 2020). Unfortunately, the opportunity to promote Macedonian wine and to make new collaborations at these events is lost. For the wine as a product, it is crucial to represent the country of origin.

One of the events in North Macedonia that is directly aimed at promoting Macedonian wines is the 'Vranec World Day', which was organized online in 2020 and was held for the second year in a row by the association "Wines of Macedonia". Vranec is the most important and leading variety for red wine production, which participates with $38.4 \%$ of the planted vineyards (Wines of Macedonia, 2020a).

This variety is planted on nearly 11,000 hectares, making North Macedonia the largest wine producer of this variety. It is a comparative advantage of Macedonian and Balkans wines, so activities are undertaken to popularize it. By promoting this variety, it indirectly affects the increase of the export of Macedonian wines from other varieties (Inovativnost, 2020).

The Republic of North Macedonia is by far the largest exporter of the countries in the region. Its wines are mostly exported to countries in the region, but in recent years there have been successful examples of exports to Western Europe and China. The largest winery and the largest exporter of wine is Tikves Winery. From the surrounding countries, the only major exporter of wine is Greece (Zdravkovska-Stojcevska, 2020). Most of the exported wine is still bulk, although now the wine is of much better quality and it is produced according to much higher standards than 40 years ago. The process of increasing export in bottles versus the sale of bulk wine is long and laborious, and it requires large investments by wineries, focusing on quality and building a Macedonian wine brand. However, the progress is evident, for comparison, $95 \%$ of the wine that was exported in 2005 was bulk, while in 2019, it participated with $57 \%$ of the total wine export (Pancevska, 2021).

According to the data from the Customs Office of the Republic of North Macedonia (2020), in terms of exported quantities, in the period from January to November 2020 , as compared to the same period in 2019, the export of bulk wine remained the same, but the export of bottled wine had a double-digit decline of $17.66 \%$ as is shown in Graph 1. 
Graph 1: Total export of Macedonian wine in the first 11 months of 2018, 2019 and 2020 (in quantity - HL)

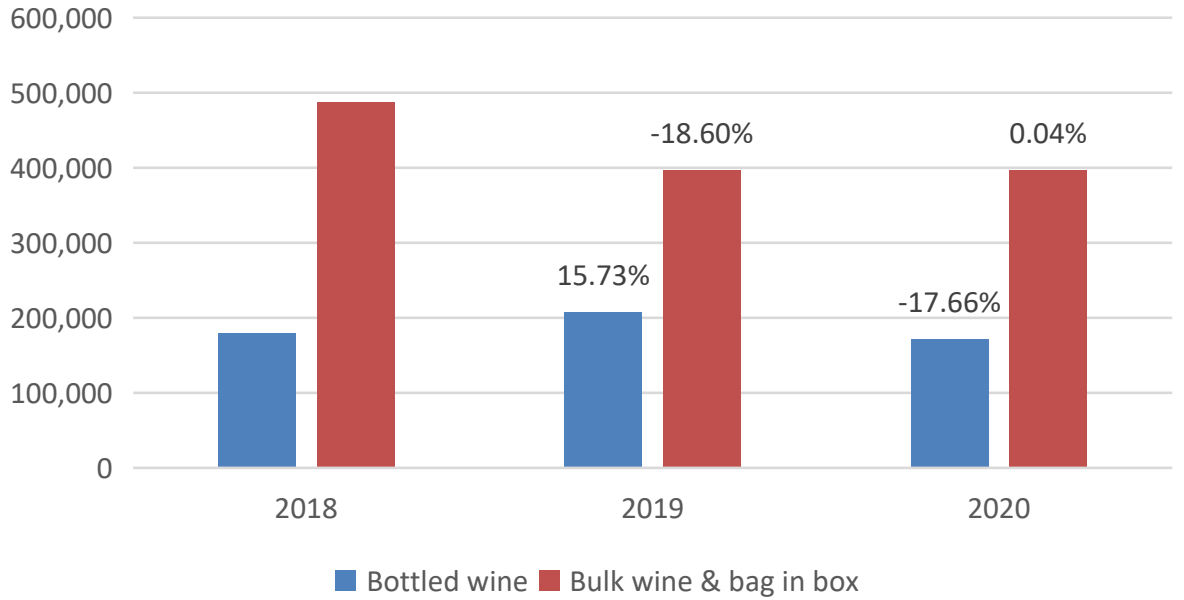

Source: Customs Office of the Republic of North Macedonia, 2020

In terms of value, in the same period (January-November 2020) as compared to 2019 , there was a decline in export for bulk and bag in box wine of $2.90 \%$, while bottled wine declined for $14.57 \%$, as shown in Graph 2. This confirms that the decline in wine sales was much more felt in the sales of bottled wines, which only confirms the fact that as a result of the pandemic, consumers became oriented towards buying cheaper wine.

Graph 2: Total export of Macedonian wine in the first 11 months of 2018, 2019 and 2020 (in value - euros)

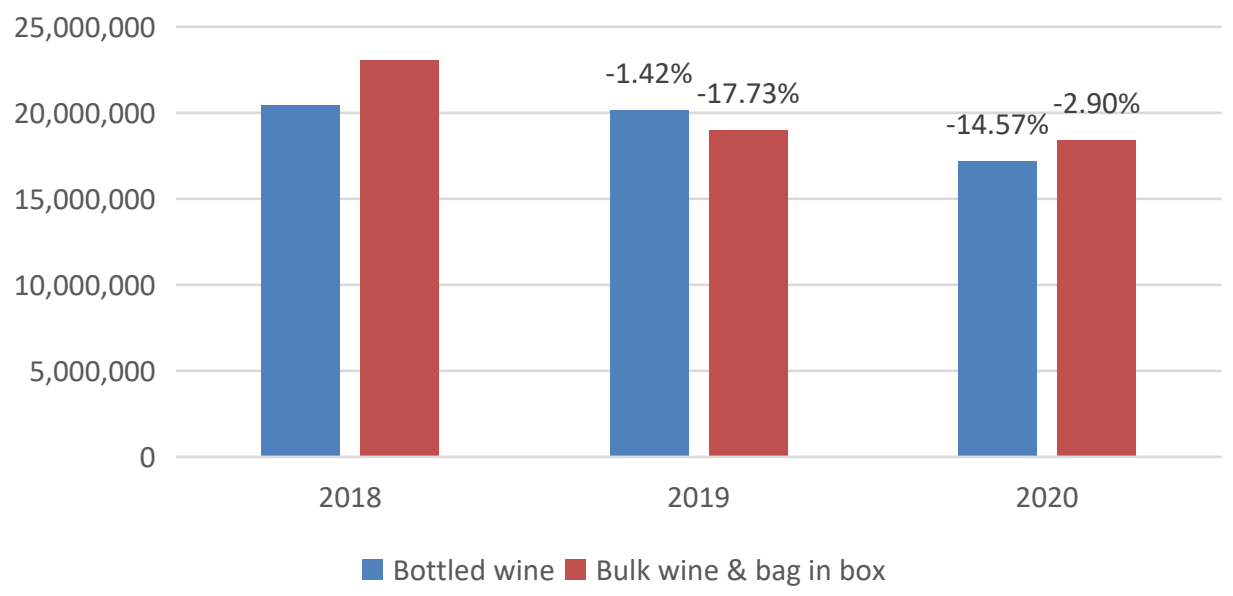

Source: Customs Office of the Republic of North Macedonia, 2020 
On the other hand, there were no significant changes in the prices of bulk and bottled wine in the first 11 months of 2020, as can be seen in Graph 3. But in the telephone interview held on December 20, 2020, E. Milosevska from the association "Wines of Macedonia" pointed out that the effects of the price reduction are expected to be felt in 2021, because Germany kept the agreed prices for bulk Macedonian wine for 2020, but in 2021 announced 4-5 euro cents reduction per 1 liter of bulk wine.

Graph 3: Average export price of Macedonian wine from 2018 to 2020 (January-November period)

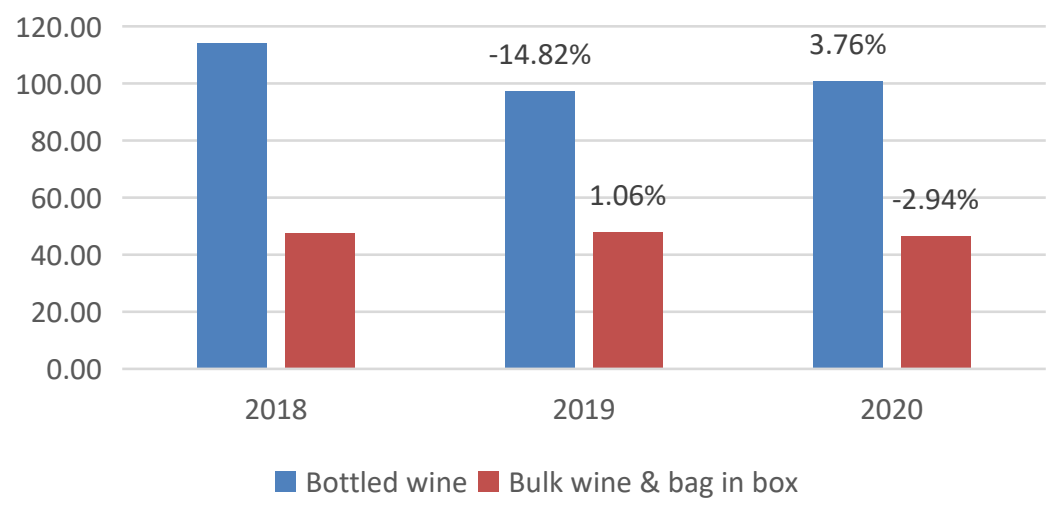

Source: Customs Office of the Republic of North Macedonia, 2020

In the first 11 months of 2020, the largest share in quantity in the overall wine export of the Macedonian wines, had the bulk wine with $63 \%$, while bottled wines participated with only $30 \%$. On the other hand, in terms of value, the share of sales of bulk and bottled wine was approximately the same. The share in export in quantity and value is shown in Graph 4.

Graph 4: Participation of certain types of wine in the total export of Macedonian wine in the period January-November 2020 in quantity (left) and value (right)
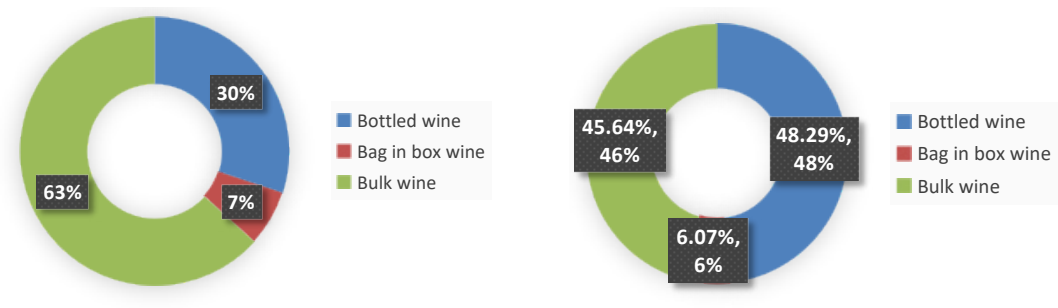

Source: Customs Office of the Republic of North Macedonia, 2020 
According to the Customs Office of the Republic of North Macedonia (2020), the largest wine exports in the first 11 months of 2020 were achieved in Germany, followed by the countries in the region: Serbia, Croatia, Bulgaria and Slovenia. What they all have in common, is that there is a decline in the export as compared to the first 11 months of 2019, which is certainly due to the new market situation with Covid-19. Moreover, almost all exports to Germany are bulk wine, and the export in the comparable period is almost $18 \%$ smaller. Export to Serbia which is the largest export market for Macedonian wines, also fell to $18 \%$ in 2020 as compared to 2019 . The only market from the TOP five export markets that had an increase compared to 2019 is Bulgaria, where export in the first 11 months of 2020 increased by $22.12 \%$, compared to the same period in 2019.

This market in 2020 exceeded export to Bosnia and Herzegovina which was one of the five largest export markets by value in 2019 (Trade map, 2021). Export to Bosnia and Herzegovina in the first 11 months of 2020, in comparison to the same period in 2019 , decreased by $35.59 \%$ which is the largest decline compared to other key export markets for Macedonian wines (Customs Office of the Republic of North Macedonia, 2020).

For this paper, an online survey of export managers in the largest Macedonian wineries was conducted in order to collect primary data.

When asked how Covid-19 affected the economic situation of their company, all of the respondents stated that the virus had a negative impact on the operation of the winery, and $30 \%$ said that the pandemic significantly deteriorated the situation, as shown in Graph 5.

Graph 5: Impact of Covid-19 on the economic situation of Macedonian wineries

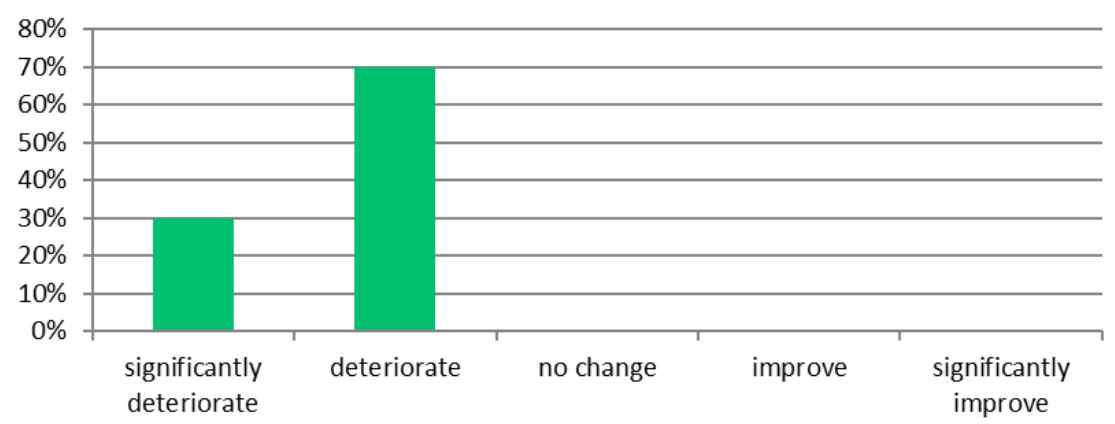

Source: Custom online survey

The second question referred to how the pandemic affected the export prices. $20 \%$ of export managers claimed that prices increased, $30 \%$ argued that they remained the same, and even half of the respondents (50\%) stated that they have decreased, as shown in Graph 6. 
Graph 6: Impact of Covid-19 on the export prices of Macedonian wineries

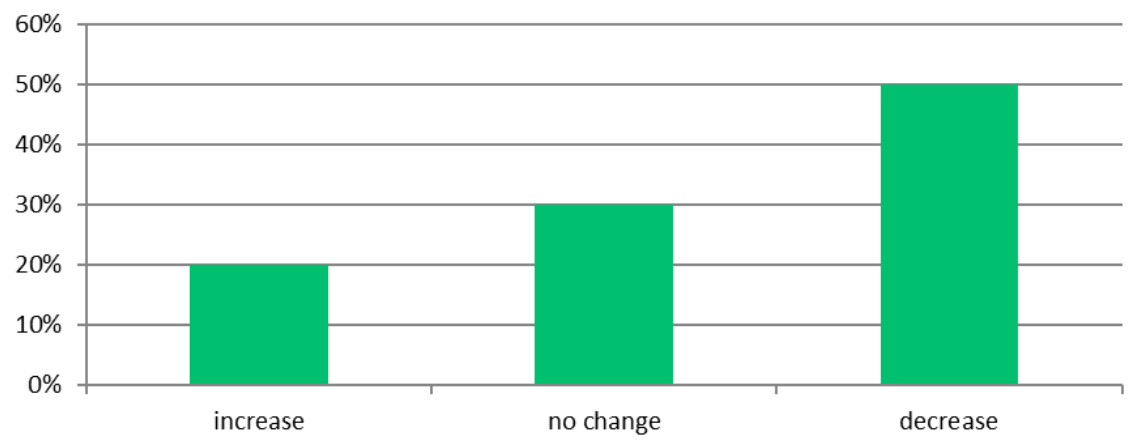

Source: Custom online survey

Restaurants and hotels were the weakest sales channel in the export of Macedonian wines during the pandemic. When asked which sales channels showed the best results in $2020,80 \%$ of export managers stated - food chains and supermarkets and $30 \%$ of the respondents pointed out the online merchants, direct sales and speciality wine shops. Only $10 \%$ chose their online store, but none of the respondents pointed to the HORECA channel, as shown in Graph 7 below. This only confirms the fact that in 2020, sales were diverted to trade, completely bypassing the HORECA sector.

Graph 7: The best sales channels for Macedonian wineries on the international markets for 2020

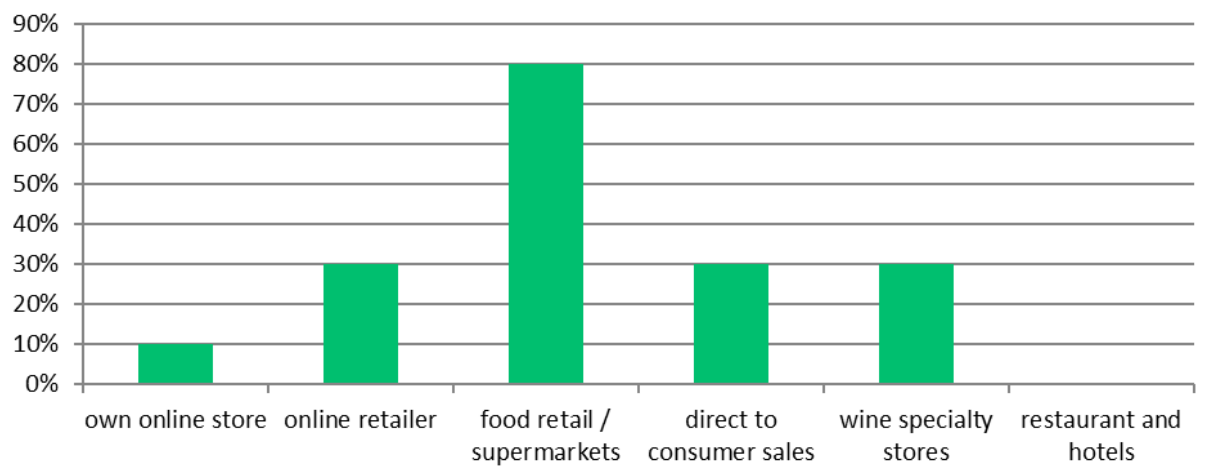

Source: Custom online survey

In the survey, export managers were asked to select 3 export markets that were most affected during the pandemic and $60 \%$ of them mentioned Germany and the Balkan countries. They were followed by the United States, China and other countries which were listed by $40 \%$ of the answers, while $10 \%$ said that it affected sales in the UK, Denmark, Belgium and Russia. The answers to this question are shown in Graph 8 below. 
Graph 8: Export markets of Macedonian wines in which Covid-19 had the greatest

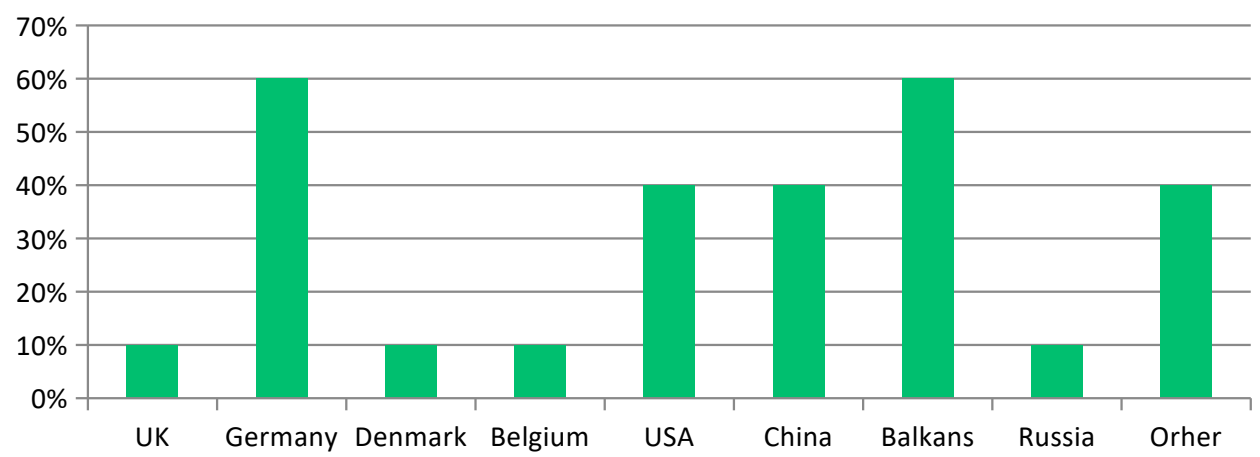

Source: Custom online survey

Graph 9 summarizes the answers about the impact of Covid-19 on activities in terms of marketing and sales. $70 \%$ of export managers stated that they started or increased communication through social media and that they have offered special price discounts. $40 \%$ offered a delivery service and increased online advertising, while some of them (30\%) offered online tastings. The smallest part (20\%) stated that they opened an online store or switched to new shopping or online channels.

Grafikon 9: Marketing activities of Macedonian wineries taken in response to the pandemic

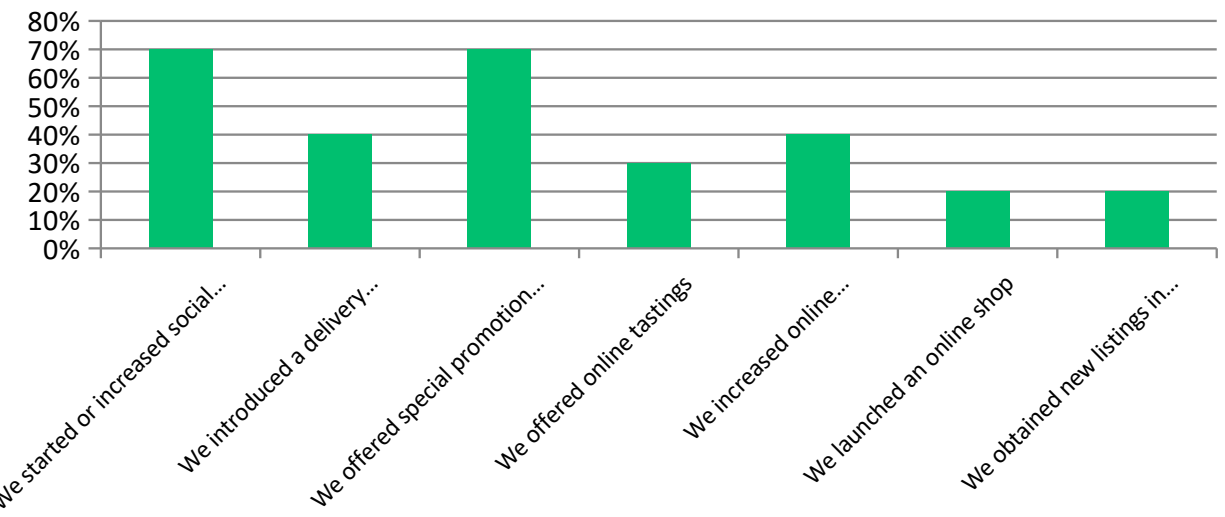

Source: Custom online survey 
Globally, according to the online survey by Loose \& Nelgen (2020), conducted in late 2020 on more than 3,400 wine professionals from 49 countries, the following conclusions were made:

- The majority of the international wine producers stated that they were negatively affected by Covid-19, and only $15 \%$ said they had benefited during the pandemic. Small wineries and exporters were mostly affected because they didn't have as much influence in retail chains as the large wineries.

- Online channels, food retailers and direct sales had the best results in 2020. The same sales channels are expected to benefit the most in 2021. The most affected were the sales of restaurants and hotels, followed by export and wine speciality shops, which are expected to partially recover in 2021.

- Globally, the most affected export markets for 2020 were the United States, the Netherlands and China \& Hong Kong, while Scandinavia and Sweden remained more robust. Overall, recovery prospects fall short of compensating for the decline experienced in 2020. In comparison to the losses, recovery prospects are particularly large for Sweden.

- Communication and direct sales to consumers were the most prominent reactions from wine producers around the world. They started using new tools such as social media (60\%), online tasting (37\%) or new online stores $(23 \%)$. Every second specialized wine store and every third restaurant offered delivery services to their customers. Online communication and online advertising increased when businesses resumed operations after the first lock.

\section{State measures to reduce the impact of Covid-19 on the Macedonian wine industry}

In all countries, more or less, state measures were introduced to help wineries and growers at least partially overcome the crisis. Some of them were aimed at improving their cash flows, some at paying employees, others at facilitating the harvest for wineries and vine growers, etc (International Organisation of Vine and Wine, 2020).

Without adequate state support, there is a real danger of a complete collapse of the Macedonian wine industry which provides annual export of about 50 million euros and provides work and social security for about 30,000 individual agricultural holding, 12,000 seasonal workers and more than 2,500 employees in 74 registered domestic wineries (Faktor, 2020). The industry also has an additional contribution, because Macedonian wine is the ambassador of the Republic of North Macedonia 
in the region and the world, and also, one of the few products that are exported with added value (The Economic Chamber of Macedonia, 2020).

During the purchase of grapes for the 2020 harvest, the large wineries were most affected by the winegrowers because they were expected to buy the most of the grapes. An additional problem was caused by the unfavourable weather conditions long dry periods during the vegetation of the vines, severe rains during the ripening, as well as the diseases that badly affected the vineyard and the quality of the grapes in 2020 (Lokalno, 2020).

Perceiving the particularly difficult situation, in which the wineries found themselves, a situation where the main channel for selling Macedonian wine became catering facilities and where there is a significant reduction in the frequency of visitors and consumption, the Economic Chamber of Macedonia (2020) appealed to the Ministry of Agriculture, Water Economy and Forestry to consider the possibility of reducing the VAT on the domestic market for Macedonian wine. Although this was expected to contribute in the long run in terms of keeping the consumption of Macedonian products at home, such a proposal was not accepted.

In North Macedonia, a Law on Financial Support was adopted by a short procedure to reduce the consequences caused by Covid-19 on the production, the harvest and the wine industry in general. This law provides for a package of measures to help the wine industry. According to this law, the financial support consists of: support of 6 dinars per kilogram for grapes from harvest 2020 which is handed over to registered producers of wine intended for other grape products (not wine) and wine distillate; and then, 2 dinars per kilogram for grapes intended for wine production or export of wine grapes. The law also provides for a reduction of $30 \%$ of transport costs for exported bottled wine and $20 \%$ of transport costs for exported bulk wine in the first 10 months of 2020. It also provides support for the export of wine grapes from the 2020 harvest (Dejure, 2020):

- 2 dinars per kilogram for quantities up to 12 million kilograms

- 3 dinars per kilogram for quantities from 12 to 25 million kilograms

- 4 dinars per kilogram for quantities over 25 million kilograms

In the past period, the Government of the Republic of North Macedonia made an effort and intervened with the support of six million euros, which mostly went as direct support for winegrowers, and very little for domestic wineries. The measure to support transport costs for export is the only one that means direct support and amounts to only one million euros. Some wineries sell their wine exclusively on the domestic market in their tourist facilities that in this period didn't work. They are not covered by any measures. (The Economic Chamber of Macedonia, 2020). 


\section{CONCLUSION}

The covid-19 pandemic has seriously affected the Macedonian wine industry. Given the importance of this industry in the Macedonian economy, the insufficient emphasis was put on establishing timely measures to mitigate the decline in sales of Macedonian wines on the domestic market and the export to foreign markets.

As a product that is drunk for enjoyment in a company and whose consumption is primarily aimed at hospitality facilities, the closure of the HORECA sector directly affected the operation of Macedonian wineries. The fear and the inability of people to collect, socialize and drink wine, diverted consumption at home, and shopping in retail or online.

Due to the reduction of sales in the domestic and international markets, it is necessary for the wineries to completely reorganize the work and grab the opportunity to open new sales channels, digitize sales and launch new types of packaging at a cheaper price segments.

Regarding the decline in the export of bottled wine, there will be an increase in stocks of unsold wine, since wineries won't be able to sell on the market due to the pandemic. Hence, there is a need for active involvement of the state with certain packages of measures that will help the most vulnerable entities and the industry in general. All this requires organized and united efforts of Macedonian wineries to take timely measures that will help the industry to "stay on its feet" in this hectic period.

A recommendation for further research is the conduction of a survey that will cover a larger sample, including not only the export managers, but also those responsible for sales in the domestic market, employees in the marketing departments of wineries, as well as vine-growers and employees in relevant state institutions. This kind of survey would give a complete picture of the long-term consequences of the pandemic on the Macedonian wine industry. This could be more than essential for the Macedonian wineries in order to make forecasts and strategies for sales and marketing after the crisis, and to take the most effective measures, which will result in a complete recovery of the wine industry. 


\section{REFERENCES:}

1. Customs Office of the Republic of North Macedonia, 2020, "Export report for 2020" prepared by Association "Wines of Macedonia" and Ministry of Agriculture, Forestry and Water Economy and Wines of Macedonia

2. Dejure, 2020, "Law on financial support to reduce the consequences of the coronavirus Covid-19 on production, harvest of grapes and the wine industry", viewed 05.01.2021, https://dejure.mk

3. Faktor, 2020, "Wineries and wine traders say: Purchase prices are low because the state doesn't help" viewed 05.01.2021, https://faktor.mk/se-oglasija-vinariite-i-trgovcite-so-vino-otkupnite-ceni-se-mali-zatoa-shto-drzavata-ne-pomaga

4. In Store, 2020, "Euromonitor: digital trends in emerging markets", viewed 27 December 2020, https://instore.mk/record/14/10268/euromonitor-digitalni-trendovi-na-pazarite-vo-razvoj

5. Inovativnost, 2020, "Vranec World Day celebrated online with many visitors from around the world", viewed 07.01.2021, https://inovativnost.mk

6. International Organisation of Vine and Wine, 2020, "Covid-19 crisis impacts explained by OIV experts”, viewed 26.12. 2020, http://www.oiv.int/en/t/covid19-crisis-impacts-explained-by-oiv-experts

7. Ivanovic, T., 2020, "COVID-19 Puts Balkan Winemakers Over a Barrel", viewed 26.12. 2020, https://balkaninsight.com/2020/09/23/covid-19-puts-balkan-winemakers-over-a-barrel/

8. Lokalno, 2020, “Tikves: Purchase prices for grapes are higher so that we don't lay off workers and can survive as a winery", viewed 26.12.2020, https://lokalno.mk

9. Loose, S., Nelgen, S., 2020, PROWEIN BUSINESS REPORT 2020 "THE EFFECTS OF COVID-19”, Geisenheim University, Institute of Wine and Beverage Business Research, 04 01. 2021, https://www.researchgate.net

10. Ministry of Economy, 2020, "Bekteshi and Hodza on " Vranec World Day": Wine industry has great export potential, with greater promotion Macedonian wine will become recognizable on world markets", viewed 05.01. 2021, https:// economy.gov.mk/vest/439

11. Pancevska, K., 2021, "There are many hills and slopes on the Macedonian wine roads", 07.01.2021, https://www.novamakedonija.com.mk/ekonomija

12. ProWein, n.d., "The latest ProWein Business Report 2020 is now available: Covid-19 is the biggest challenge for the global wine industry", viewed 05.01.2021, https://www.prowein.com/en 
13. The Economic Chamber of Macedonia, 2020, "Domestic wineries request that the draft Law on Amendments to the Law on Value Added Tax also include wine", viewed 26 December 2020, from https://www.mchamber.mk/Default. aspx?mId=3\&evid=38977\&lng=1

14. The IWSR, n.d., "Covid-19 presents opportunities for the US still wine market", viewed 07 January 2021, from https://www.theiwsr.com/covid-19-presentsopportunities-for-the-us-still-wine-market/

15. Tikves Winery, 2020, Press release, viewed 22.12.2020, https://tikves.com.mk/ wp-content/uploads/2020/09/Tikves_Soopshtenie_Berba_06.09.2020.pdf

16. Tikves Winery, 2021, Report on the situation on the domestic wine market for 2020

17. Trade map, 2021, viewed 07 January 2021, from https://www.trademap.org/Country_SelProductCountry_TS.aspx?nvpm

18. Wine of Macedonia, 2020c, "Economy", viewed 29 December 2020, https:// winesofmacedonia.mk/key-figures/

19. Wines of Macedonia, 2020a, Presentation "Export comparative analysis 20102019 "

20. Wines of Macedonia, 2020b, "History", viewed 29 December 2020, http://winesofmacedonia.mk/wine-industry/

21. Zdravkovska-Stojcevska, B., 2020, "Macedonia is the 29th largest exporter in the world with wine export worth 51.8 million dollars", viewed 05.01.2021, https://izvoz.mk 
Snezana Ristevka-Jovanovska

Ana Dimovska

\section{MARKETINŠKE AKTIVNOSTI I PRODAJA MAKEDONSKE VINARIJE U USLOVIMA COVID-19}

\section{SAŽETAK}

Covid-19 je imao utjecaj na cjelokupno poslovanje makedonskih vinarija, a direktna posljedica je pad prodaje na domaćem i izvoza na međunarodno tržište. HORECA sektor je djelomično ili u potpunosti prestao sa radom u svim državama. Kriza je sasvim ili djelomično smanjila marketinške troškove, odlaganjem ili otkazivanjem planiranih projekata. Vinarije nisu uspjele prodati planirane količine te su bile prinuđene značajno smanjiti otkup berbe 2020. godine u odnosu na prethodne godine.

U radu je predstavljen veliki broj podataka dobivenih od Udruženja makedonskih vinarija, Uprave carine Republike Sjeverne Makedonije, Ministarstva poljoprivrede, šumarstva i vodoprivrede Republike Sjeverne Makedonije, Državnog inspektorata poljoprivrede te internet članaka koji sadrže teme relevantne za istraživanje. Predstavljeni su i dodatni podaci prikupljeni od makedonskih vinarija putem upitnika koji se odnosi na poslovanje u vrijeme korona krize.

Ovaj rad predstavlja pregled problema s kojim su se suočile makedonske vinarije tijekom korona krize u pogledu marketinga i prodaje, prevashodno na međunarodnom tržištu kroz analizu pada prosječne cijene i smanjenje ulaganja u marketing.

Ključne riječi: Sjeverna Makedonija, makedonske vinarije, Covid-19, posljedice, vino

JEL: M30 